Revue belge de géographie

\title{
The social sustainability of multicultural cities: a neighbourhood affair?
}

Durabilité sociale des villes multiculturelles: une affaire de quartier?

\section{Annick Germain}

\section{(2) OpenEdition}

1 Journals

\section{Electronic version}

URL: http://journals.openedition.org/belgeo/16098

DOI: $10.4000 /$ belgeo. 16098

ISSN: 2294-9135

Publisher:

National Committee of Geography of Belgium, Société Royale Belge de Géographie

\section{Printed version}

Date of publication: 30 December 2002

Number of pages: 377-389

ISSN: 1377-2368

\section{Electronic reference}

Annick Germain, "The social sustainability of multicultural cities: a neighbourhood affair?", Belgeo [Online], 4 | 2002, Online since 31 December 2002, connection on 11 February 2021. URL: http:// journals.openedition.org/belgeo/16098; DOI: https://doi.org/10.4000/belgeo.16098

This text was automatically generated on 11 February 2021.

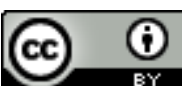

Belgeo est mis à disposition selon les termes de la licence Creative Commons Attribution 4.0 International. 


\title{
The social sustainability of multicultural cities: a neighbourhood affair?
}

Durabilité sociale des villes multiculturelles: une affaire de quartier?

\author{
Annick Germain
}

This text was translated by Mary Sweeney. She has my thanks.

1 The concept of sustainable development has no longer been defined from a strictly environmental perspective for quite a few years now. The scope of the problem has been enlarged to include its social dimensions, leading notably to a renewed focus on urban development, and more particularly, on the topic of cities' social and cultural diversity. Building inclusive cities means that sustainable development programs have repercussions on aspects of contemporary city life that are quite sensitive. In the words of the World Commission on Environment and Development (1987, p. 43), «Meet[ing] the needs of the present without compromising the ability of future generations to meet their own needs», assumes in fact that the social body remains whole. Social cohesion is another expression that is in style right now, although it is a rather unconvincing one nonetheless, for most definitions stress what social cohesion is not, rather than what it is. The notion of social exclusion is then evoked in order to deal with the sizeable rifts that threaten social cohesion. But here again we are left with a catch-all term that does not help our thinking advance very easily ${ }^{1}$. To have a clearer idea of how the land lies, we must then scope out the terrain of real-life cases.

In a collected edition entitled The Social Sustainability of Cities. Diversity and the Management of Change, we showed that this social question can no longer be reduced to issues of distributive justice, as was the case in the 1960s (Polèse and Stren, 2000). Rather, it is inextricably linked to how well economic and socio-cultural differences can coexist (Séguin and Germain, 2000). Finding ways to prevent or limit segregation and other forms of social division affecting the urban tissue is an important issue for cities. 
This is why managing diversity has become one of the main challenges facing many metropolitan centres world-wide.

3 Montreal makes an interesting laboratory in this respect, for although its cosmopolitanism is not new, the socio-demographic evolution that has taken place over the past thirty years has drastically changed the metropolitan landscape. Migratory flows have intensified and diversified greatly, and this change is all the more formidable given that the metropolitan area receives the bulk of all immigrants admitted to Quebec.

In the pages that follow we intend to hark back to several research projects carried out over the past few years on Montreal's ethnocultural diversity from an urban standpoint. To begin with, we will show how immigration is a particularly sensitive question in Montreal (indeed even explosive on occasion), then we will present a brief geographical survey of immigration in Montreal. In the second part, we will spotlight the results of a study carried out during the first half of the 1990s on interethnic coexistence at the neighbourhood level. And in the last part, we will explore conceptual elements that have been highlighted by more recent studies on the challenge that managing ethnocultural and religious diversity at the neighbourhood level poses for municipalities. For in the end, everything, or almost everything, seems to play out at this level, at least at a first glance.

\section{Immigrant neighbourhoods: a sensitive question}

5 If we agree to define a sensitive question as a question that is delicate, giving rise to discomfort and embarrassment, but revealing at the same time, of both a given social context and of what it comprises, then there can be no doubt that in Montreal immigration is a sensitive question. Quebec's relationship with immigration remains ambiguous; immigration represents both an essential resource for a society afflicted by an extremely low birth rate as well as a potential threat for a society defining itself mainly by its status as a Francophone minority in America, all the while counting a formerly very powerful Anglophone minority among its members. Indeed, although the government of Quebec adopted a law in 1977 obliging the children of immigrants to attend French schools in order to counter the linguistic transfers that penalized Francophones for a long time, immigrants' identification with Francophone Quebec still remains suspect even today.

6 The political issues that have been grafted onto these demographic issues are also touchy, as neo-Quebecers display a certain lukewarmness towards with the Independence Project of the Parti Québécois². We will not place further emphasis on this aspect, although it still bears mention as the «National Question» colours most dossiers, be they social and cultural as well as economic or demographic.

But the question of immigration also plays out at the level of urban space. This question is all the more sensitive in Montreal, since the metropolitan area attracts close to ninetenths of all immigrants admitted to Quebec (between 25,000 and 50,000 per year) and the City of Montreal ${ }^{3}$ accommodates $45 \%$ alone. Likewise, the Anglophone minority (defined here as persons having English as their mother tongue) is also concentrated on the Island of Montreal, where this group accounts for $13.7 \%$ of the population of the Montreal urban area, which includes the former municipalities (Canada Census, 1996). In addition, most immigrants settled in the Western part of the city as much as 
possible, close to the Anglophone neighbourhoods. Today, immigrants are beginning to settle in many neighbourhoods in the Eastern part, areas that are inhabited mainly by French Canadians.

8 The residential localization of new arrivals adds again to the uneasiness. Indeed, many wonder how immigrants, strongly concentrated in immigrant neighbourhoods where occasionally they are in the majority (making up to $60 \%$ of the total population of a neighbourhood), can integrate into the host society. Moreover, the Quebec Ministry of Immigration dreams not only of dispersing immigrants across the island but also, and above all, across the province in order to avoid having «two Quebec's in one» - a cosmopolitan one and a very homogeneous one, two realities that are nonetheless already firmly fixed. But there is a difference between dreams and reality. In actual fact, the only action the Ministry can take is on the localization of refugees.

At the start of the 1990s, this Ministry launched a vast research program on Immigration and Urban Dynamics. Immigration levels had risen sharply at the beginning of the decade. This increase was welcome in a way, since both the Canadian and Quebec governments had set high quotas that were often difficult to meet. But the Ministry was troubled by the repercussions that such an influx of immigrants could have on the social fabric of the metropolitan area. It must be said that during the same era, in North America as well as in Europe, racist incidents in cities were multiplying and these violent outbursts seemed to forecast that interethnic coexistence would be difficult. How were urban populations living with these significant demographic and cultural changes on a daily basis? What was multicultural Montreal's current bill of health?

It was within this framework that our research project on interethnic coexistence in multiethnic neighbourhoods in the Montreal area was launched (Germain et al., 1995). This research project was funded jointly by Quebec's Ministry of Immigration and Cultural Communities and by the City of Montreal.

\section{Modes of coexistence in multiethnic neighbourhoods}

11 Right at the beginning, an agreement was reached with the project sponsors to emphasize the specifically urban dimensions of immigrant integration in Montreal and to explore neighbourhood life in its community organization (or associative) dimension and through that of social interaction in public spaces (or public sociability).

12 Furthermore, it was decided that stress should be placed on the most multiethnic neighbourhoods of the metropolitan area. Although Montreal has been an «immigrant city» ${ }^{4}$ for a long time, until the 1980 s it was essentially made up of 'ethnic' neighbourhoods, sectors of the city that ethnic groups had «made their own» (the Greek, Portuguese, and Italian quarters, etc.), while still living alongside other immigrants. These ethnic neighbourhoods followed a long tradition of social segmentation of urban space along linguistic, ethnocultural, and religious lines. The French Canadians and English Canadians had always had their own distinct neighbourhoods as well as institutions (schools, charitable organizations, churches, etc.). In fact, within the Anglophone group, the social differentiation of urban space was further broken down according to nationality-of-origin (Scottish, English, and Irish), with the Irish sometimes moving closer to the French Canadian areas and institutions due to their religion. This model of integration through social segmentation 
(Germain and Rose, 2000) was adopted up until the 1980s by immigrants arriving from Europe.

Since the end of the 1970s, Canadian immigration opened up to immigrants from Third World countries in particular, and so immigrant flows have diversified considerably at the level of ethno-national origin. Today, Quebec receives immigrants ${ }^{5}$ from almost everywhere. Different migratory waves have succeeded each other, characterized notably by significant immigratory waves from Asia, from the West Indies, and more recently from countries in Eastern Europe and North Africa. This «new» immigration has diversified the older ethnic neighbourhoods to such an extent that today there are many neighbourhoods where immigrants all hail from very different countries. However, this does not stop many of these neighbourhoods from being dominated by certain ethnic groups. For example, the old Greek quarter (where two-thirds of the Greek population lived in the 1970s) now holds only a third, living alongside Indians, Sri Lankans, Haitians, Latin-Americans, etc. These ethnic group concentrations have not completely disappeared. It must be noted that immigrants' residential rationale varies; certain ethnic groups are highly dispersed in urban space (the North Africans, for example), others have the tendency to group together (certain Asian groups, for example). But overall, the number of multiethnic neighbourhoods is increasing, even in the suburbs located off the Island of Montreal.

In this respect it is interesting to note that even if immigrants are mainly concentrated on the Island of Montreal, a certain fanning-out to off-Island areas can be observed (see Figure 1 on the relative concentration of immigrants in the Montreal Metropolitan Area, Canada Census 1996). These suburbs off the Island of Montreal receive immigrants who, like many others, achieve the periphery once their socio-economic condition improves. But there are also suburbs, very well-to-do as well, in which the owners of single-family residences have arrived directly from their country-of-origin without passing through the inner city, due to real-estate networks controlled by their fellow countrymen (Charbonneau and Germain, 2002). 
Figure 1. Relative concentration of immigrants in the Montreal census. Metropolitan Area in 1996, by Census Tract.

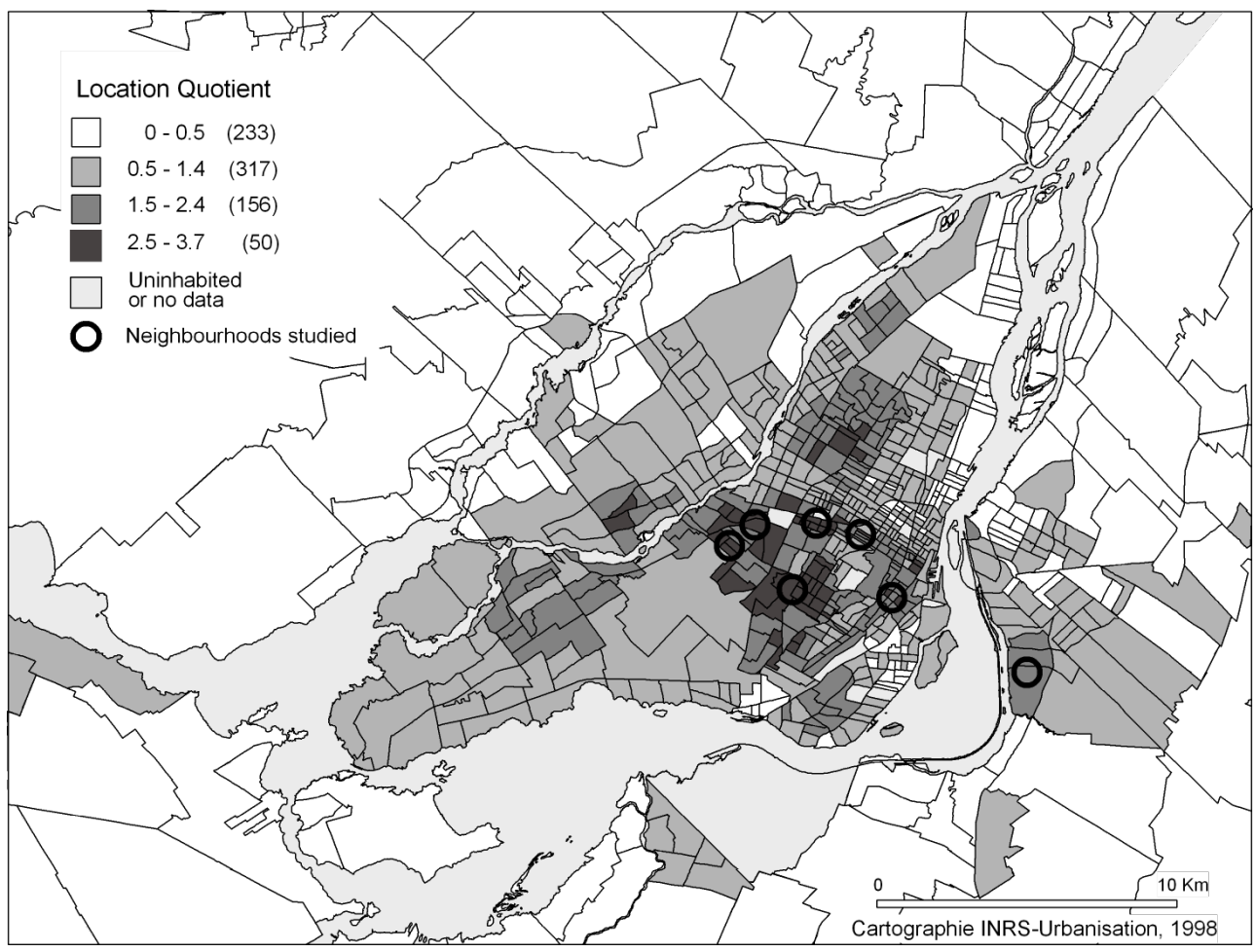

Each of the seven neighbourhoods ${ }^{6}$ (see Figure 1) featured in this study is a very particular case that illustrates the reality of the multiethnic neighbourhood. These neighbourhoods vary tremendously in fact: from relatively affluent neighbourhoods to poor ones; from suburbs to inner city neighbourhoods; from older immigrant neighbourhoods to newer immigrant ones; from neighbourhoods where the urban tissue is very dense to neighbourhoods where it is more spread-out; as well as variations between housing and living conditions, etc.

Our sponsors were preoccupied with two questions:

1. To understand the participation of immigrants and members of cultural communities in neighbourhood life better by observing the places where this dynamic plays out and the forms that it takes.

2. To unearth the factors that facilitate or, on the contrary, hinder harmonious relations.

In order to find answers to these two questions, each neighbourhood was subject to a battery of qualitative research approaches. These include: researching its historical settlement by various ethnic groups; studying its urban morphology (including that of public spaces); interviewing key respondents on their extensive knowledge of neighbourhood dynamics; systematically observing modes of social interaction in a sample of public spaces (observation hours and seasons were varied); analyzing neighbourhood associative dynamics and the role played by cultural communities (this term is used to designate people who are not of French Canadian origin). After having completed the portrait of each neighbourhood, a comparative analysis was conducted in order to let common points emerge, and to explore the two questions brought up above in a more global manner. 
18 Two characteristics from among these common points are worth mentioning as they concern our topic directly. In the first place, detailed analysis of information on voluntary associations reveals that ethnic groups play an important role in community development action. Ethnic groups were often even the first ones to set up a structure of community aid that helped neighbourhood residents who were financially disadvantaged, marginalized, or newly arrived. A good number of these associations were part of different consultative frameworks (the Neighbourhood Consultation Boards, for example) in order to coordinate their efforts. These networks occasionally played a key role in dealing with interethnic crises or tension. This was particularly noteworthy in a relatively poor neighbourhood long stigmatized as being violent and a Black minority stronghold.

Various consultative frameworks have been institutionalized since the time of the study. Today, the City of Montreal has twenty Intersectorial Neighbourhood Consultation Boards, sometimes accused of acting as the main representatives for public authorities in the neighbourhood, as if the latter only spoke with one voice. Furthermore, the Quebec Ministry of Immigration and Cultural Communities, since renamed the Ministry of Citizen Relations and Immigration, has seriously decreased the funding it provides to monoethnic associations, preferring instead to encourage the creation (or the reconversion) of multiethnic organizations, that is, those open to a broader clientele. This shift in orientation, dictated by the desire to combat both the withdrawal of ethnic groups into themselves and ethnic group ghettoization, sometimes poses a problem when it comes time to pinpoint the needs of certain immigrant groups. In principle, associations should be relaying the problems and needs of their fellow countrymen to public authorities, but in actual fact they are blocked from doing so because anything that appears to be a form of civic representation by particular ethnic groups is regarded with suspicion (Germain and Sweeney, 2002). It seems the ideals of multiculturalism are not valued everywhere, not by a long shot.

The second characteristic that was observed derives from the study of modes of social interaction in public spaces (such as parks, public squares, subway stations, commercial thoroughfares, and the like - meeting places, in short) ${ }^{7}$. A common pattern emerges, best described as the peaceful but distant coexistence between users of diverse ethnic origins. In these spaces, local users seem to respect a code of common courtesy that allows them to take pleasure to be in a public space while still maintaining a certain distance from other users. The presence of this modus vivendi does not prevent sporadic tensions from erupting, but it nonetheless allows public space to be shared in a rather peaceful and non-conflictual way, even in very densely-occupied neighbourhoods. This coexistence does not lead to really genuine form of inter-group social mixing, however, as social exchanges remain bounded according to age, gender and ethnic origin. But a type of acclimatization or socialization to diversity is present nonetheless, that allows these neighbourhoods to benefit from a certain public animation and conviviality, essential for inclusive city building. Of course, this public animation varies strongly according to the type of urban tissue. In an American-style residential suburb, spaces for social interaction in public are not many! In that case however, shopping centres serve the function of meeting place.

21 Lastly, another of this vast study's findings also bears mention. However, this is more of a hypothesis, nurtured by our comparative neighbourhood observations. In the case of neighbourhoods dominated by one or two groups who affirm themselves as being 
dominant, ethnocultural diversity seems to depolarize relations between ethnic groups. The arrival of a massive number of immigrants of various origins in a neighbourhood is often accompanied by the idea that one's status as a minority is deactivated in this urban space («Why bother about it when we're all minorities»). In a way, these immigrant neighbourhoods can be places of integration, where new arrivals feel they can carve out a niche for themselves in the city (Simon, 1992). The role that the neighbourhood plays in building an inclusive city is not negligible, as long as it does not become banishment zone, holding pens for those who are not welcome, and that prevent them from leaving and improving their lot. In this respect, Montreal seems to be a city where urban space is relatively accessible. The housing market is more fluid (the majority of Montrealers are tenants) than in other metropolitan centres of comparable size and the housing prices are much lower than in Toronto or Vancouver. In addition, if one considers the global level rather than the local micro-level, the social fabric of many neighbourhoods is relatively heterogeneous. Lastly, a decent public transportation system facilitates mobility between different parts of the city, and encourages its discovery. As some studies reveal, this turns out to be important for the settlement process of female immigrants (Rose and Ray, 1997).

All in all, Montreal can be considered more of an inclusive city than can other cities of comparable size. But its administrators are well aware of the fragility of this «loose cosmopolitanism». Municipal diversity management is thus on the agenda of a large number of municipalities in the Montreal area.

\section{The challenge of municipal diversity management at the neighbourhood level}

According to Polèse and Stren, the social sustainability of a city rests in part on the local policies implemented in order to build an inclusive city, be these housing, welfare, or transportation policies (Polèse and Stren, 2000). Although the domain of immigration is not really a municipal prerogative as higher levels of government are responsible for immigrant admission and integration, some cities are aware that immigration poses a challenge for them. The City of Montreal has had an «intercultural» policy since the mid-1980s, managed by an Intercultural Affairs Bureau that comes directly under the Mayor of Montreal.

In its 2000-2002 action plan, entitled Construire ensemble. Une ville à l'image du monde. Interventions en relations interculturelles (Building Together. A City in the World's Image. Interceding in intercultural relations), the City maintains that it wants to: contribute towards immigrant settlement; stand guard over the principles of equity, nondiscrimination, and non-exclusion; take the needs of citizens of all origins into account in its offer of services; and strengthen the cosmopolitan character of Montreal.

In the research program we have been carrying out for the past two years ${ }^{8}$, we decided to examine two types of municipal diversity management practices: the offer of sports and recreation services, and how urban planning divisions manage requests for the establishment or enlargement of minorities places of worship. Several municipalities in the Montreal area were selected for study, mainly according to their immigrant populations. The initial findings reveal a great diversity of approaches from one municipality to another. But here we will emphasize mainly the experience of the City 
of Montreal in the sports and recreation field when faced with the multiethnicity of neighbourhoods.

\section{Managing recreation services in multiethnic neighbourhoods}

The way the local milieu is configured strongly affects what recreation services (and sports) are offered or demanded, as well as how these activities are managed. In effect, managing a playing field in a neighbourhood that has a large White non-immigrant majority plus an immigrant minority is very different from managing the same field in a multiethnic neighbourhood that is home to many recently-arrived immigrants, like those neighbourhoods discussed previously. But the «permeability» of local policies to ethnocultural difference varies according to the overall orientations (or philosophies) that guide the municipality on matters of social integration. In this respect, our studies show that a large disparity exists between the orientations of different municipalities in the metropolitan area, and even from one municipal service to another within the same municipality! At one end of the spectrum are municipalities that adopt «universalist» management practices that do not take ethnocultural differences into account. Immigrants must learn how to integrate into their new society, so encouraging them to hold onto the traditions of their country-of-origin is not advisable. At the other end, the municipality tries to be tuned in to cultural differences when planning what recreation services are to be offered. For instance, soccer is more successful than baseball in multiethnic neighbourhoods. Quite obviously, most municipalities lie somewhere between the two, but those lying on the extreme ends of the spectrum are not uncommon.

Whatever the overall positions taken, most actors are convinced of the virtues of immigrant integration through sports and recreation activities, because these are situations of unconstrained coexistence: one chooses one's sport, but one does not always choose where one lives or works! This situation ties in with what Jean Remy called the paradox of the inconsequential: «...des lieux peuvent être d'autant plus importants que les rencontres qui s'y déroulent sont sans consequence sur les grands enjeux de la vie sociale» («...places can be all the more important because the encounters that take place in them have little consequence for the broad issues of social life») (Remy, 1990, p. 99). But this sometimes leads to the development of rigid policies: it is not unusual to see municipal officials refusing to allow young immigrants to form soccer (or football) teams based on their nationality. Intergroup mixing is considered to be an indispensable condition. However, this condition is not always enforced in the case of adult groups.

The socio-demographic composition of the local milieu has an impact that naturally concerns municipal administrations trying to take their clientele's characteristics into account through institutional adaptation. This is notably the case with the City of Montreal, especially since more and more it is entrusting the management of its recreation facilities and programs to NGOs or associations with which it signs funding agreements. Since 1998, partnership has been the City's preferred mode of recreation management rather than direct service provision. Of course, these associations must respect certain criteria (they must adhere to the City's objectives, be situated in the milieu, etc.). But once the agreement is finalized, the City loses its decision-making 
power. It thus finds itself dependent on local dynamics. For example, in several immigrant neighbourhoods, the associations in charge of recreation facilities are managed by non-immigrants or by members of Montreal's long established cultural communities, which can pose a problem when it comes time to take the demands of more recent immigrants into account. To make matters worse, the latter are generally poorly organized at the community level and find it difficult to make their demands known.

The multiethnicity of a neighbourhood sometimes makes accommodating the coexisting demands of one group or another difficult. For example, some groups submit specific requests regarding swimming pools (separate swim-times for men and women) out of respect for their religion, but this limits other groups' use of the pool (for example, parents accompanying children of different sexes). Sporting traditions in different countries are also often very diverse, and end up in competition with each other because facilities are limited (for example, a playing field can be laid out for soccer, baseball, or cricket). Thus is it sometimes necessary to make a choice between different sports activities.

Since dealing with idiosyncratic demands puts the Charter of Rights and Freedoms into the game, the Intercultural Affairs Bureau offers support to local bureaucrats. It has just published a guide on reasonable accommodation in order to help municipal civil servants best solve all the difficulties they meet when faced with such a diverse clientele, as discriminatory faux pas are easy to make.

31 As these examples show, diversity management is not just the preserve of central political and administrative authorities, but is a current that runs through the daily practice of municipal actors.

\section{By way of conclusion}

The neighbourhood is then pivotal to inclusive city building, as it represents a critical space that can make all the difference. But one should not be mistaken about the relationship that its inhabitants have with this space. Immigrants do not necessarily identify with the neighbourhood they reside in (especially if it is a disadvantaged one) and do not necessarily put down roots there either. In our study, a great many neighbourhoods are peopled by those who have settled there and by others who are just passing through. But overall, residential mobility is high in Montreal. Nevertheless, it should be acknowledged that in general people do not move very far away, and rarely to a completely different neighbourhood.

As far as community organizations and associations are concerned, their clientele is rarely located in one single neighbourhood. For several years now however, local policies tend to glorify the neighbourhood, making it a reference point for all forms of intervention. Discrepancies between local policies and the practices of inhabitants may then very well exist. And certainly the role that the neighbourhood plays in terms of residents' practices and notably in terms of immigrant community organization networks should not be denied at all. Falling back on the concept of the neighbourhood-as-village should be avoided, however, as it does not really correspond with the urbanity of a metropolitan city like Montreal. 
Nonetheless, the fact certainly remains that the neighbourhood constitutes an ideal laboratory for observing a plural and cohesive city in the making.

\section{BIBLIOGRAPHY}

CASTEL R. (1991), «De l'indigence à l'exclusion, la désaffiliation. Précarité du travail et vulnérabilité relationnelle», in DONZELOT J. (éd.), Face à l'exclusion. Le modèle français, Paris, PUF, pp. 137-168.

CHARBONNEAU J. et GERMAIN A. (2002), «Les banlieues de l'immigration», Recherches sociographiques, XLIII, 2, pp. 311-328.

GERMAIN A., ARCHAMBAULT J., BLANC B., DANSEREAU F., ROSE D. (1995), Cohabitation interethnique et vie de quartier, Québec, Gouvernement du Québec, Ministère des Affaires internationales, de l'Immigration et des Communautés culturelles, collection Études et Documents, $\mathrm{N}^{\circ} 12$.

GERMAIN A. and ROSE D. (2000), Montreal. The Quest for a Metropolis, London, Chichester, John Wiley \& Sons.

GERMAIN A. et SWEENEY M. (2002), La participation des organismes s'occupant d'immigrants et/ou de communautés culturelles aux instances de concertation de quartier, Research report prepared for the City of Montreal. Montreal, INRS-Urbanisation, Culture et Société.

MCNICOLL C. (1993), Montréal, une société multiculturelle, Paris, Belin.

Polèse M. and Stren R. (eds.) (2000), The Social Sustainability of Cities. Diversity and the Management of Change, Toronto, University of Toronto Press.

REMY J. (1990), «La ville cosmopolite et la coexistence interethnique», in BASTENIER A. et DASSETO F. (eds.), Immigration et nouveaux pluralismes. Une confrontation de sociétés, Bruxelles, De Boeck-Université, pp. 85-106.

ROSE D. and RAY B. (in collaboration with CHICOINE N. and CHARBONNEAU J.) (1997), Discovering the City? Mobility patterns in the use of services during immigrant women's settlement process in Montreal, text of a paper presented at the annual reunion of the Canadian Association of Geographers, St. John's, Newfoundland, August 19-23.

SEGUIN A.-M. and GERMAIN A. (2000), «The Social Sustainability of Montreal: A Local or a State Matter?», in POLÈSE M. and STREN R. (eds.), The Social Sustainability of Cities. Diversity and Management of Change, Toronto, University of Toronto Press, pp. 39-67.

SIMON P. (1992), «Belleville, un quartier d'intégration» Migrations et sociétés, IV, 19, pp. 45-68. WORLD COMMISSION ON ENVIRONMENT AND DEVELOPMENT (1987), Our Common Future, Oxford and New York, Oxford University Press. 


\section{NOTES}

1. Social exclusion implies deprivation of financial resources and limited access to basic collective social goods and services. It also encompasses the notion of disaffiliation, as proposed by Robert Castel. This entails exclusion from the social networks and kinships that usually provide a sense of belonging and security (Castel, 1991).

2. During the last Referendum on the issue of Independence, the Premier of Quebec accused «money and the ethnic vote» of having deprived Quebec of victory in favour of sovereignty association.

3. Since January 1, 2002, the 29 municipalities of the Island of Montreal have merged, forming the (new) City of Montreal. However, since our studies pre-date this merger, we are retaining the former municipal divisions. As a matter of interest, the Montreal Metropolitan Area has 3,400,000 inhabitants, the Island of Montreal has 1,700,000 and the (former) City of Montreal has 1,000,000 inhabitants.

4. In fact, unlike American cities, Montreal was not recognized as a cosmopolitan city before the start of the $20^{\text {th }}$ century. However, it has been multicultural for a long time, since it was populated by the French, British, Scottish, and Irish (McNicoll, 1993).

5. These immigrants can generally be divided in the following manner (although this varies highly from year to year): one half are independent immigrants, one quarter are refugees, and one quarter are immigrants accepted under the Family Reunification Program.

6. Neighbourhood dimensions varied from 8,000 to 44,000 inhabitants. Since Montreal has a fairly strong neighbourhood-building tradition, identifying and demarcating them was not too difficult. The proportion of immigrants in all these neighbourhoods (immigrants being people who are not born in Canada) was higher than $30 \%$, sometimes reaching $60 \%$.

7. In total, thirty sites were observed, with a dozen observation periods per site.

8. The Appropriation of Urban Space and Municipal Diversity Management Practices, a research program funded by the Social Sciences and Humanities Research Council of Canada and coordinated by Annick Germain and Francine Dansereau.

\section{ABSTRACTS}

In multiethnic cities sustainable social development partly depends on the coexistence of social and cultural differences and on the diversity management policies. Several researches directed by the author on Montreal's multiethnic neighbourhoods show to what extent the neighbourhood remains an ideal laboratory for understanding how those modes of coexistence develop. One should however avoid basing all forms of intervention in the field of diversity management on a concept of the neighbourhood-as-village which does not correspond with the urbanity of some social practices, at least in a metropolitan city like Montreal.

Dans les villes pluriethniques, le développement social durable repose en partie sur la coexistence des différences sociales et culturelles et sur les politiques de gestion de la diversité. Plusieurs recherches menées par l'auteur sur les quartiers multiethniques de Montréal illustrent à quel point le quartier reste un laboratoire d'observation privilégié pour comprendre la construction de ces modes de coexistence. On aurait cependant tort de baser toutes les interventions en matière de gestion de la diversité sur une conception du quartier-village qui ne 
correspond pas à l'urbanité des pratiques sociales citadines, du moins dans une ville comme Montréal.

\section{INDEX}

Mots-clés: quartier, multiculturalisme, développement social durable, immigration, Montréal Keywords: neighbourhood, multiculturalism, sustainable social development, immigration, Montreal

\section{AUTHOR}

\section{ANNICK GERMAIN}

Institut national de la recherche scientifique, Urbanisation, Culture et Société, Montréal (Québec), Canada, Annick.Germain@inrs-ucs.uquebec.ca 